\title{
Correction to: Comment on "Efficacy of a single intra-articular injection of ultra-high molecular weight hyaluronic acid for hip osteoarthritis: a randomized controlled study"
}

\author{
Valter Santilli ${ }^{1}$ (D) Federica Alviti $^{1} \cdot$ Marco Paoloni $^{1} \cdot$ Massimiliano Mangone $^{1} \cdot$ Andrea Bernetti $^{1}$
}

Published online: 24 March 2018

๑) Springer-Verlag France SAS, part of Springer Nature 2018

\section{Correction to: \\ European Journal of Orthopaedic Surgery \& Traumatology https://doi.org/10.1007/s00590-018-2132-z}

The original version of this article unfortunately contained a mistake. The first and last names of the authors were interchanged. The correct author names are given below.

Valter Santilli · Federica Alviti · Marco Paoloni ·

Massimiliano Mangone $\cdot$ Andrea Bernetti

The original article has been corrected.

The original article can be found online at https://doi.org/10.1007/ s00590-018-2132-z.

Andrea Bernetti

andrea.bernetti@uniroma1.it

1 Department of Physical Medicine and Rehabilitation,

Sapienza University of Rome, Rome, Italy 